\title{
OPEN Bioactivities of Allium longicuspis Regel against anthracnose of mango caused by Colletotrichum gloeosporioides (Penz.)
}

Dionisio de Guzman Alvindia ${ }^{1,3}$ \& Mark Anthony Angeles Mangoba ${ }^{1,2} \bowtie$

The present study focused on the effect of Allium longicuspis extracts (ALE) against anthracnose of mango fruit. In vitro tests (mycelial growth and conidial germination) showed that, ALE concentrated from 0.75 to $2.5 \mathrm{~g} \mathrm{~L}^{-1}$ completely inhibited the growth of Colletotrichum gloesporioides. Cytoplasmic discharge, mycelial and conidial blasts were clearly observed when applied with ALE. The minimum effective concentration (MEC) of ALE at $0.75 \mathrm{~g} \mathrm{~L}^{1}$ can be applied as protective, curative and simultaneous treatment in mango fruit to inhibit the anthracnose infection. Efficacy of garlic extract was relatively superior to synthetic fungicide based on protective, curative and simultaneous treatments. Twenty chemical components were detected in ALE based on GCMS analysis (Table 1). The six major components were the following: oleyl alcohol, methyl ether (42.04\%), $\gamma$-sitosterol $(15.85 \%)$, , 24-norursa-3.12-diene (5.62\%), 1-octadecanol methyl ether (4.23\%), n-pentadecanol (3.95\%) and 2-vinyl-4h-1 3-dithiine (3.76\%). The findings support the potential use of ALE as an alternative to synthetic fungicide.

Mangifera indica L. popularly known as mango, is the second most important agricultural fruit in the Philippines with a production yield of 899.014 metric tons in $2016^{1}$. Losses is as high as $2-33 \%$ due to anthracnose disease ${ }^{2}$. Colletotrichum gloeosporioides (Penz.) Penz. and Sacc is a plant pathogenic fungi that dominantly attack mango fruit and main cause of anthracnose disease $\mathrm{s}^{3-7}$. The fungus is ubiquitous and responsible for many fruit diseases of other tropical fruit such as banana, avocado and many others ${ }^{6-7}$. Furthermore, it infects the inflorescence, young leaves and branches, and its fruit ${ }^{3,5}$.

In the past, synthetic fungicides (dithiocarbamate, benomyl, thiabendazole, prochloraz, imazalil and copper fungicides) are used to control anthracnose infection ${ }^{3,8,9}$. However, some of them are no longer used for mango export in other countries and is somehow restricted because of public concern over exceeding maximum residue limit $(\mathrm{MRL})^{3}$. Further, due to continuous used of synthetic fungicides, fungal pathogen developed resistance and it contaminates our environments ${ }^{10}$. Therefore, the screening of potential fungicides derived from natural products (plants) may help to overcome this problem.

Allium spp. on the other hand, has been widely utilized not only as spices for food but also for treatment against wide range of microorganisms including fungi ${ }^{11-17}$. Organosulfur compounds are mainly produced by Allium spp. This compound penetrates the cell membrane and undergo thiol-disulphide exchange reactions in proteins $^{18}$. This information is mainly the basis of fungal death ${ }^{19-20}$. Hence, organosulfur compound has multiple targets inside the cell and this fact can make it tough for the pathogen to develop resistance ${ }^{18}$.

Limited knowledge exists on the effect of Allium longicuspis or commonly known as "garlic: wild type" against C. gloeosporioides in vitro and in vivo tests. This may be useful in managing anthracnose incidence in mango fruit and as an alternative to synthetic fungicides. Moreover, this study determined the chemical components of A. longicuspis extracts and antibiotic effect to fungal pathogen C. gloeosporioides.

\footnotetext{
${ }^{1}$ Food Protection Division, Philippine Center for Postharvest Development and Mechanization, Department of Agriculture, Muñoz, Nueva Ecija, Philippines. ${ }^{2}$ Department of Bio-Resource and Food Science, College of Life and Environmental Sciences, Konkuk University, Seoul, South Korea. ${ }^{3}$ Center for Natural Sciences and Environmental Research (CENSER), De La Salle University, Taft Ave., Manila, Philippines. ${ }^{\circledR}$ email: ma_mangoba@yahoo.com
} 


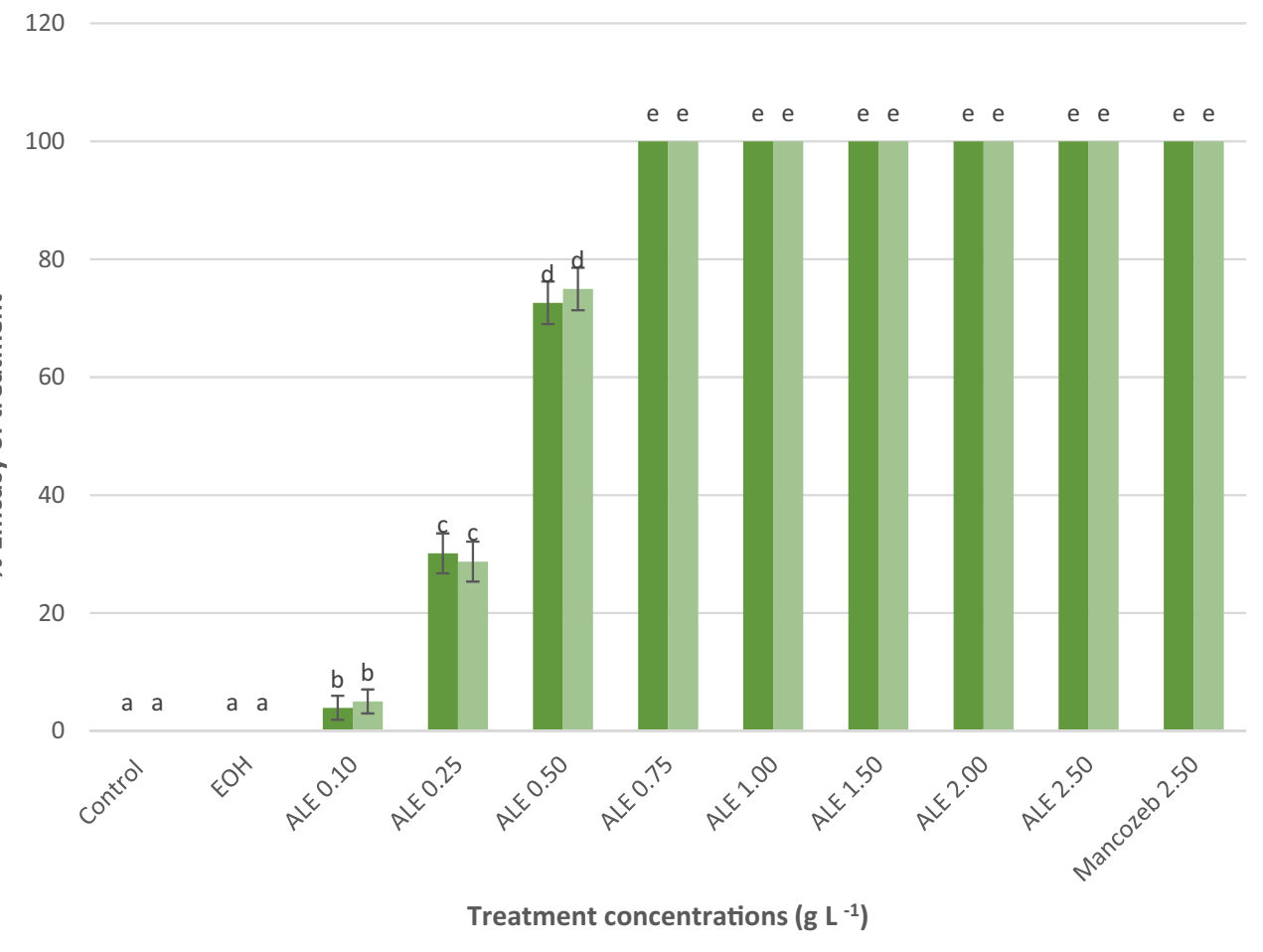

Figure 1. Percent inhibition on the mycelial growth of C. gloeosporioides 7 days after inoculation. Values followed with the same letter is not significantly different based on Tukey's HSD test at $\mathrm{p}<0.05$. Green and light green represents trial 1 and 2 . The vertical bars acted as standard error $( \pm)$ of mean of the three biological replicates cited in the method section, $N=33$ per trial.

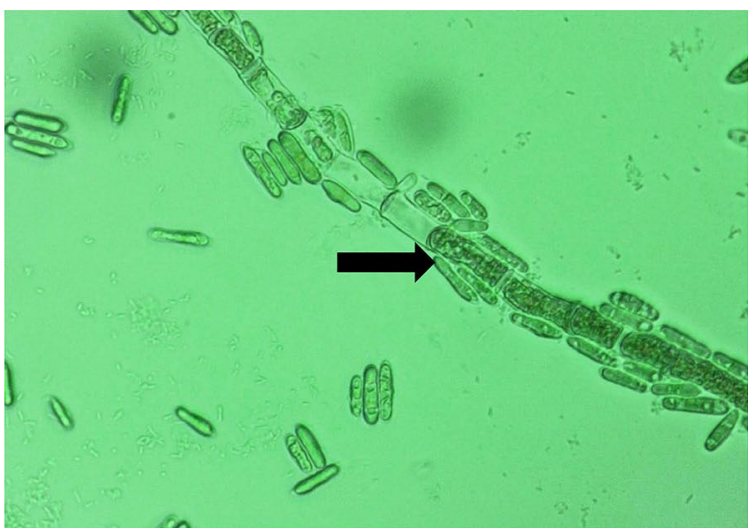

a

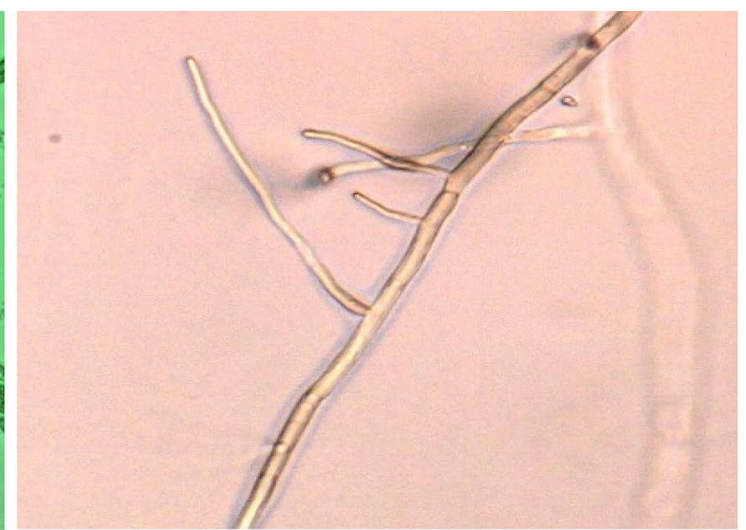

b

Figure 2. Mycelia of C. gloeosporioides (a) treated with ALE, (b) treated with water, 7 days after treatment as seen under the microscope.

\section{Results}

In vitro analysis revealed that, ALE severely affected the mycelial growth of $C$. gloeosporioides with respect to the untreated control (Fig. 1). Complete inhibition of mycelial growth was observed starting from $0.75 \mathrm{~g} \mathrm{~L}^{-1}$ concentration of ALE and statistically comparable with the synthetic fungicides (Mancozeb) at $2.5 \mathrm{~g} \mathrm{~L}^{-1} \mathrm{con}^{-}$ centration in terms of inhibitory effect on the mycelial growth. Lower concentration $\left(0.75 \mathrm{~g} \mathrm{~L}^{-1}\right)$ of ALE was needed in vitro to achieve complete inhibition of mycelial growth as compared with the conventional synthetic fungicide (Mancozeb $2.5 \mathrm{~g} \mathrm{~L}^{-1}$ ). The activity was directly organized and proportional, as the higher the treatment concentration, the greater the greater the effect on fungal inhibition, until it reaches the maximum rate of inhibition. Thus, adding more concentration of ALE will no longer affect the inhibition of the test fungi. The ALE-pathogen interaction showed the presence of mycelial blast, 7 days after treatment (Fig. 2a) as seen under microscope (Keyence, VHX-5000, USA) observations. However, C. gloeosporioides treated with water showed vigorous mycelial growth after treatment (Fig. 2b). 


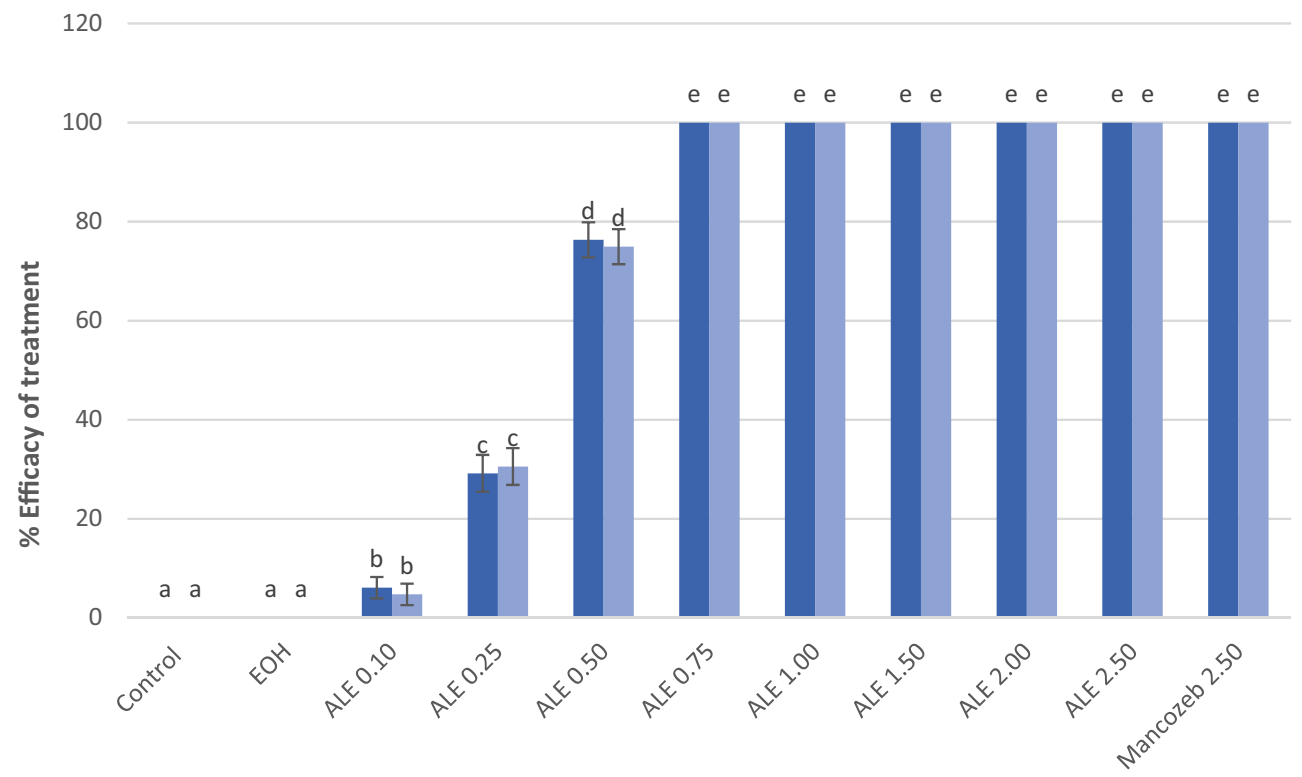

Treatment concentrations $\left(\mathrm{g} \mathrm{L}^{-1}\right)$

Figure 3. Percent conidial germination of C. gloeosporioides, $48 \mathrm{~h}$ after inoculation. Values followed with the same letter is not significantly different based on Tukey's HSD test at $p<0.05$. Blue and light blue bars represents trial 1 and 2 . The vertical bars acted as standard error $( \pm)$ of mean of the three biological replicates cited in the method section, $N=33$ per trial.

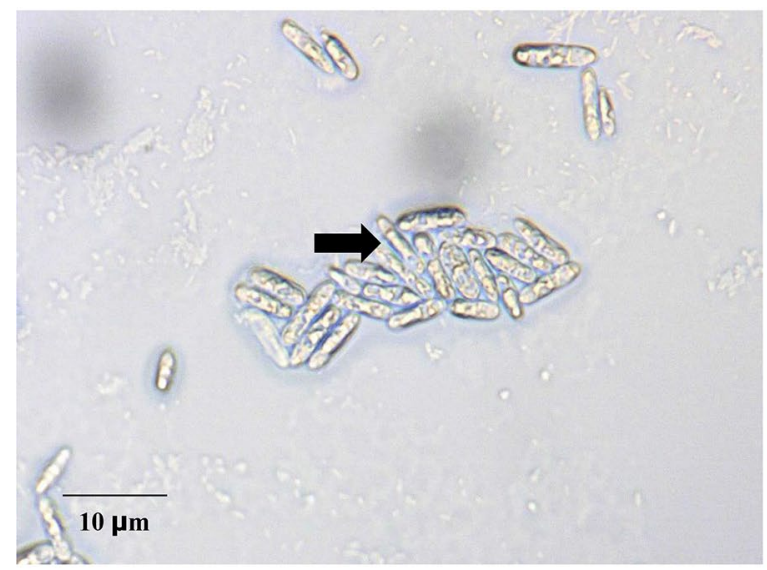

a

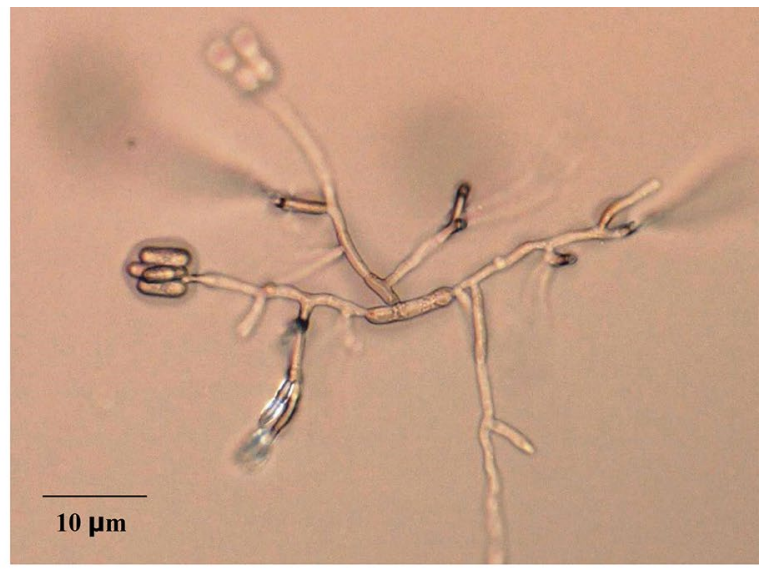

$\mathrm{b}$

Figure 4. Conidia of C. gloeosporioides (a) treated with ALE (b) treated with water, $48 \mathrm{~h}$ after treatment as seen under the microscope.

The ALE at $0.75 \mathrm{~g} \mathrm{~L}^{-1}$ concentration completely inhibit the conidial germination of C. gloeosporioides (Fig. 3). Cytoplasmic discharge and conidial blast was vividly observed on C. gloeosporioides treated with ALE (Fig. 4a) but conidial germination was noticed at C. gloeosporioides treated with water (Fig. $4 \mathrm{~b}$ ), $48 \mathrm{~h}$ after treatment.

Meanwhile, after 7 days, mango fruit treated with ALE resulted no discoloration nor detectable phytotoxicity was observed even at highest concentration of $2.5 \mathrm{~g} \mathrm{~L}^{-1}$ (Fig. 5a). However, fruit treated with C. gloeosporioides suspension resulted in sunken, discolored, black lesions that looks like "alligator skin" on the surface of inoculation sites of mango (Fig. 5b).

On in vivo test, direct application of ALE $24 \mathrm{~h}$ before, after and simultaneously with inoculation of C. gloeosporioides significantly reduced the anthracnose incidence on mango fruit (Fig. 6). The ALE gave greater efficacy against anthracnose of mango as compared to conventional synthetic fungicide. The curative effect of ALE at $0.75 \mathrm{~g} \mathrm{~L}^{-1}$ (66.81-68.89\% efficacy) was far better than the synthetic fungicide (Mancozeb $2.5 \mathrm{~g} \mathrm{~L}^{-1}$ ) - having zero or no effect at all. Preventative activities of ALE at $0.75 \mathrm{~g} \mathrm{~L}^{-1}$ provided complete control against anthracnose of mango; synthetic fungicide only got 3.17-4.31\% efficacy. However, ALE was statistically comparable with the synthetic fungicide in terms of efficacy and inhibitory effect (100\% effective) in simultaneous activities. Generally, 


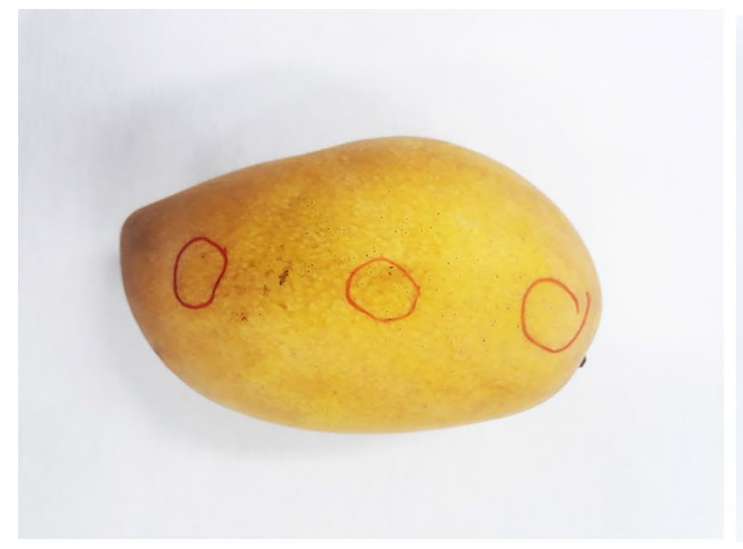

a

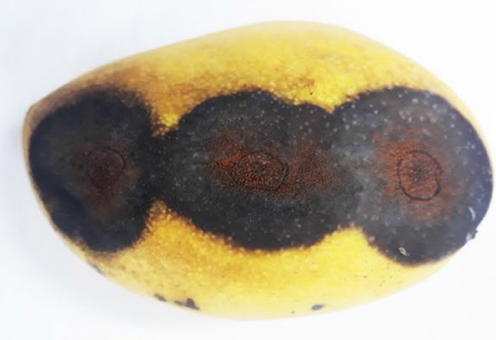

b

Figure 5. Mango treated with ALE (a) treated with C. gloeosporioides (b), 7 days after treatment.

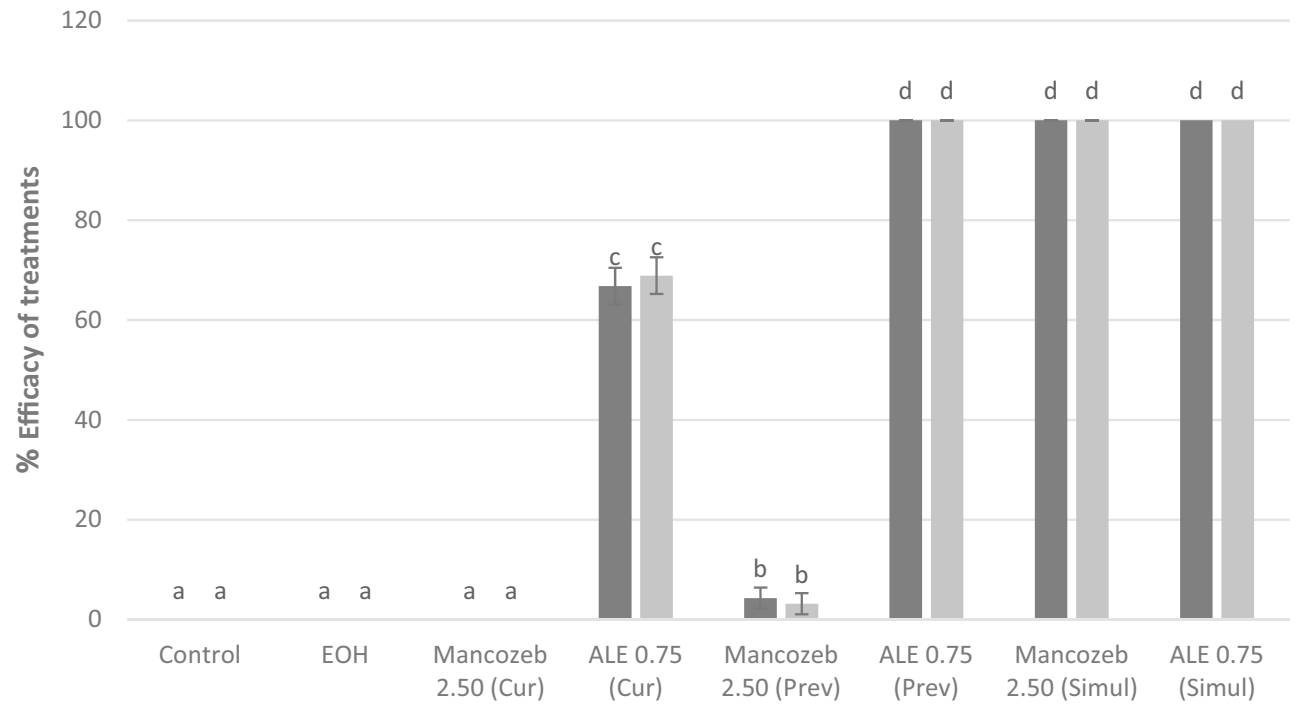

Treatment concentrations $\left(\mathrm{g} \mathrm{L}^{-1}\right)$

Figure 6. The efficacy of treatments 7 days after inoculation. Values followed with the same letter is not significantly different based on Tukey's HSD test at $\mathrm{p}<0.05$. Black and gray bars represents trial 1 and 2 . The vertical bars acted as standard error $( \pm)$ of mean of the three biological replicates cited in the method section. Curcurative, Simul simultaneous, Prev preventative.

ALE as preventative, curative and simultaneous activities were relatively superior to commercially synthetic fungicide (Mancozeb) in terms of efficacy and potency.

Twenty chemical components were detected in ALE based on GC-MS analysis (Table 1). The six major components were the following: oleyl alcohol, methyl ether (42.04\%), $\gamma$-sitosterol (15.85\%), , 24-norursa-3.12-diene (5.62\%), 1-octadecanol methyl ether (4.23\%), n-pentadecanol (3.95\%) and 2-vinyl-4h-1 3-dithiine (3.76\%).

\section{Discussions}

In the current investigation, ALE successfully inhibited growth of C. gloeosporioides (mycelia and conidia) in in vitro tests. Cytoplasmic discharge, mycelial and conidial blasts were clearly observed when applied with ALE. Parallel findings were observed by other scientists, which associates on the disruption and damaged of the fungal cell that leads into death ${ }^{18-20}$. The ALE at $0.75 \mathrm{~g} \mathrm{~L}^{-1}$ is hereby recommended, because at this concentration, complete fungal inhibition was observed with no detectable phytotoxicity on mango fruit. Although Allium spp. are known for its strong aroma, which is mainly caused by organosulfur compound. However, based on the phytotoxicity test conducted, the aroma of garlic can be detectable on the first $24 \mathrm{~h}$ after application, beyond that, no garlic aroma was observed. Further, those organosulfur compound was thermally unstable and naturally degraded by nature ${ }^{21}$. 


\begin{tabular}{|l|l|c|}
\hline RT & Name & $\%$ Area \\
\hline 5.173 & 6-Methylheptan-3-ol & 3.73 \\
\hline 5.277 & 3-Vinyl-1 2-dithiacyclohex-4-ene & 0.64 \\
\hline 5.444 & 2-Vinyl-4h-1 3-dithiine & 3.76 \\
\hline 6.048 & Diallyl trisulfide & 1.29 \\
\hline 9.315 & 1-Methoxycarbonylethyl-5-methoxycarbonylpentyl ether & 0.41 \\
\hline 11.359 & Tetradecanoic acid & 0.56 \\
\hline 13.669 & $n$-Pentadecanol & 3.95 \\
\hline 15.200 & $n$-Hexadecanoic acid & 2.17 \\
\hline 15.937 & 1-Chloro-4-(1-ethoxyethoxy)-2-methylbut-2-ene & 0.96 \\
\hline 17.104 & 9.12-Octadecadien-1-ol.(Z.Z) & 1.29 \\
\hline 17.269 & Oleyl alcohol, methyl ether & 42.04 \\
\hline 17.764 & 1-Octadecanol methyl ether & 4.23 \\
\hline 17.919 & Linoleic acid, methyl ester & 1.25 \\
\hline 26.077 & Hexadecanoic acid 2-hydroxy-1-(hydroxymethyl)ethyl ester & 1.75 \\
\hline 28.746 & Octadecanoic acid 2 3-dihydroxypropyl ester & 0.88 \\
\hline 32.374 & Cholesta-4 6-dien-3-ol (3.beta.)- & 1.38 \\
\hline 32.767 & 1-Hexacosanol & 2.84 \\
\hline 32.975 & Cholesterol & 1.35 \\
\hline 34.497 & Campesterol & 2.22 \\
\hline 35.969 & I-Sitosterol & 15.85 \\
\hline 36.656 & 9,19-Cyclo-9.beta--lanostane-3.beta.25-diol & 5.62 \\
\hline 37.681 & 24-Norursa-3.12-diene & \\
\hline & & 1.83 \\
\hline
\end{tabular}

Table 1. Chemical composition of Allium longicuspis extracts.

Meanwhile, the minimum effective concentration (MEC) of ALE at $0.75 \mathrm{~g} \mathrm{~L}^{-1}$ concentration can be applied as protective, curative and simultaneous treatment on mango fruit to inhibit the anthracnose infection. The ALE exhibited a higher toxic effect on the test pathogen (C. gloeosporioides) even at a low volume concentration $(0.75 \mathrm{~g}$ $\mathrm{L}^{-1}$ ) compared with synthetic fungicide (Mancozeb $2.5 \mathrm{~g} \mathrm{~L}^{-1}$ ) as a standard control. In fact, current results showed that ALE is thrice lower than the synthetic fungicide (Mancozeb) in terms of volume concentration to achieved complete control in simultaneous and preventative application. This implies that the major components and its derivatives may have interacted in a synergistic manner; accelerating its toxic effect that leads into death. The current results and the previous findings of other scientist support the potential utilization of Allium spp. (wild and traditional type) extracts against fungi and other microbial pathogens $\mathrm{s}^{22-24}$.

The inconsistency on the results and/or effect of treatments (ALE and Mancozeb) used in in vitro and in vivo were explained by the structural level of complexity and absorptive capacity of two different media [agar (in vitro) and mango fruit (in vivo)]. The waxes (epicuticular wax layer), cuticular plates, microdomains (crystal and amorphous layer) and other physiological characteristic presents in mango peel was acted in synergistic manner; causing a low to acute toxicity of all the treatments (ALE and Mancozeb) used against the test pathogen ${ }^{25-28}$. There is also a strong evidence that C. gloeosporioides already developed resistance to Mancozeb, based on curative and preventative results. The same results were observed by Spalding et al. ${ }^{29}$, Kumar et al. ${ }^{30}$, Brent et al. ${ }^{31}$ which links the resistance of fungal pathogens of mango to conventional synthetic fungicides, including Mancozeb. On the other hand, higher efficacy of treatments (ALE and Mancozeb) was noticed in preventative over the curative test result. This could be due to the fact that, the fungal pathogen in curative tests has already established or in-set infection prior to the application of treatments. To quote "prevention is better than cure".

On the other hand, one out of six major components of the identified compound from ALE was known for its biological activities. First, gamma sitosterol (steroid) was known for its anti diabetic activities ${ }^{32}$ and known potent inhibitor of complement $\mathrm{C} 1$ component ${ }^{33}$. It has been reported for anticancer activity through growth inhibition of the cancer cells. It also has cytotoxic effect against colon and liver cancer cell lines thru regulation and induction of the apoptotic pathways of the cell. Second, 2-vinyl-4h-1,3-dithiine, a member of dithiins compound ${ }^{34}$. Dithiins are organosulfur compound formed thru the breakdown of allicin from a garlic ${ }^{35}$. The toxic activities of garlic extract may be rationalized by presence of organosulfur and its derivatives ${ }^{36}$. However, oleyl alcohol methyl ether, 24-nourse-3,12-diene and 1-octadecanol methyl ether is a new compound whose biological activity is yet to ascertained.

Plant extracts as fungicide present two major characters. First, safe, natural and eco-friendly; second was less resistance development against target organisms ${ }^{37}$. In general, an organism can able to developed resistance into pure chemical compound but not in to a complex or mixture compounds ${ }^{37-38}$. Complex or mixture of compounds will further strengthen its effect on the target organisms. Such complexities were favorable in the broad target spectrum, because different organisms respond differently into single compounds ${ }^{39}$. Further, it reduces the potential development of genetic resistance and/or development of behavioral desensitization of an organism ${ }^{40}$. 
A. longicuspis possessed excellent antifungal effects against plant pathogenic fungi (C. gloeosporioides) and can be used as a replacement and/or auxiliary with conventional synthetic fungicide in the market. Their synergistic effect in combined with other plant extracts however, should also be investigated for future research. Other factors such as mode of action and formulating fungicide derived from plant based products in such a way that improves the product stability and potency. This work is timely and relevant as an alternative cure and control the deadest pathogen, facing the world today.

\section{Methods}

Garlic and extracts preparation. The A. longicuspis were collected in Ilocos Sur, Philippines $17^{\circ} 20^{\prime} \mathrm{N}$ $120^{\circ} 35^{\prime} \mathrm{E}$. It has a white to purple scales, bulbs are ovoid with a diameter of $2-2.5 \mathrm{~cm}$ consisting of compactly crowded truncated and angular tubers. Fresh A. longicuspis were extracted using ethanol (EOH) as a solvent, following the method of Mangoba and Alvindia ${ }^{17}$ with modifications. The A. longicuspis extracts (ALE) were vacuum filtered and evaporated using rotary evaporator. Thereafter, the obtained extracts were stored at $-80^{\circ} \mathrm{C}$ until gas chromatography and mass spectrometry (GCMS) analysis were performed.

Chemical profiling. Chemical profiling of ALE were performed following the method described by Ji et al. $^{41}$ with modifications, using GC/MS by Shimadzu. Gas chromatography was preformed using Shimadzu GC2010 model together with a Shimadzu QP2010 for mass spectrometer. Individual constituents of the ALE were characterized based on the retention time (RT) and fragmentation pattern of the mass spectra in the system of National Institute of Standards and Technology (NIST) libraries. The percent composition of the compounds were calculated from peak areas of gas chromatography.

Isolation of fungal pathogen. The ripe mango cv. "Carabao" fruit showing diseases incidence (anthracnose lesions) were acquired from local market in Nueva Ecija $15^{\circ} 35^{\prime} \mathrm{N} 121^{\circ} 00^{\prime}$ E, Philippines. The anthracnose lesions of $1 \mathrm{~cm}^{2}$ were directly removed from the infected ripe mango fruit using sterile scalpel. The infected mango tissues were dipped in 30\% sodium hypochlorite for $1 \mathrm{~min}$, rinsed thrice in sterile water for one minute and placed on sterile filter paper. Infected mango tissues were directly plated in potato dextrose agar (PDA) and placed in convection incubator (Binder: DB-56, Germany) for seven days at $25 \pm 2{ }^{\circ} \mathrm{C}$ and $70 \pm 5 \%$ relative humidity.

In vitro tests. The efficacy of ALE on the mycelial growth of the fungal isolate was evaluated following the method described by Chen et $\mathrm{al}^{42}$ with modifications. The PDA was mixed with ALE at a ranged of 0.1 to $2.5 \mathrm{~g}$ $\mathrm{L}^{-1}$ concentrations. The concentration was prepared based on the procedure by Ali et al. ${ }^{43-44}$. PDA plates treated with SW were served as negative control 1 and $\mathrm{EOH}$ for negative control 2. Ethanol as a solvent was used to determine whether it has adverse effect on the test pathogen and fruit or not. However, PDA treated with synthetic fungicide (Mancozeb at $2.5 \mathrm{~g} \mathrm{~L}^{-1}$ ) was used as a positive control.

A ten day-old C. gloeosporioides mycelial disc of $(5 \mathrm{~mm})$ was transferred into PDA plates (treated and control) and incubated as described above. The mycelial growth of $C$. gloeosporioides was measured 7 days after treatment by measuring colony diameter using a digital caliper. The efficacy of the treatment (ET) on mycelial growth was determined using the formula $\mathrm{ET}=(\mathrm{CdNC} 1-\mathrm{CdT}) / \mathrm{CdNC} 1 \times 100$; whereas: $\mathrm{CdNC} 1=$ is the colony diameter of the negative control 1 and $\mathrm{CdT}=$ colony diameter of treated with ALE and synthetic fungicide ${ }^{5}$. Two trials were arranged using complete randomized design (CRD) with three replications per treatments.

Conidial germination was assessed following the procedure described by Alvindia et al. ${ }^{5-6}$ with some modification. Test pathogen (C. gloeosporioides) was cultured on PDA for ten days and incubated as described above. After 10 days, the C. gloeosporioides plates was flooded with $5 \mathrm{ml}$ of SW and was softly scraped with sterile glass L-rod. The fungal suspension was filtered using four layer of sterile cheese cloth to separate the conidia from PDA. The conidial concentration was calculated and adjusted using hemocytometer of $10^{7}$ conidias $\mathrm{L}^{-1}$. A $100 \mu \mathrm{l}$ of the conidial suspension of the fungal pathogen was spread on water agar treated with $0.1-2.5 \mathrm{~g} \mathrm{~L}^{-1}$ concentration of ALE. Conidia receiving with SW was used as negative control and EOH for negative control 2 while conidia treated with synthetic fungicide (Mancozeb) was served as the positive control. Under the light microscope, 100 conidia were counted after $48 \mathrm{~h}$. Percent conidial germination was calculated by dividing the number of germinated conidia over the total conidia counted and multiplied by $100^{5-6}$. Subsequent abnormal bulb-like formations, bursting and spore swelling were recorded. The bio-assays were arranged as described above with two trials.

Phytotoxicity of ALE and pathogenicity of $C$. gloeosporioides. The possible toxicity of ALE to mango fruit was evaluated. The $20 \mu \mathrm{l}$ of ALE at various concentration $\left(0.75-2.5 \mathrm{~g} \mathrm{~L}^{-1}\right)$ was applied on different inoculation sites (top, middle and bottom) of mango fruit. On the other hand, the isolated fungal pathogen $(C$. gloeosporioides) was tested artificially on mango fruit for the assessment of pathogenicity tests ${ }^{5-6}$. Untreated mango fruit was served as control. Treated fruit were placed in a sterile container and kept for seven days at $25 \pm 2{ }^{\circ} \mathrm{C}$ and $70 \pm 5 \%$ relative humidity. After seven days, fruit were assessed for damage characteristic of pathogenicity and phytotoxicity test. The test was replicated thrice with two trials.

Postharvest application. The efficacy of ALE on mango fruit were evaluated using the method describe by Chen et al..$^{42}$ with modifications. Ripe mango fruit cv. Carabao were rinsed twice in SW and air dried at $25 \pm 2{ }^{\circ} \mathrm{C}$ and $70 \pm 5 \% \mathrm{RH}$, to remove other contaminants that might affect the quality of the fruit. Three mango fruit were used with three replications per treatment. Three inoculation sites of each mango fruit were determined (top, 
middle and bottom). Each inoculation sites were marked and lightly wounded using sterile "insect pins" (No. 1). The sterile insect pins were pricked once on mango fruit skin, creating a slight wound of $\leq 1.50 \mathrm{~mm}$ diameter. Thereafter, $10 \mu \mathrm{l}$ of the pathogen isolate [7 day old C. gl oeosporioides suspension $\left.\left(10^{7} \mathrm{conidia} / \mathrm{mL}\right)\right]$ and treatments (Mancozeb at $2.5 \mathrm{~g} \mathrm{~L}^{-1}$ and ALE $0.75 \mathrm{~g} \mathrm{~L}^{-1}$ ) were applied either $24 \mathrm{~h}$ before (preventative test), simultaneously and after $24 \mathrm{~h}$ (curative test) in each inoculating site. Fruit only inoculated with C. gloeosporioides suspension was served as control 1 while EOH was served as control 2. Treated fruit were kept in sterile plastic box (25 $\times 40 \mathrm{~cm}$ ) at $25 \pm 2{ }^{\circ} \mathrm{C}$ and $70 \pm 5 \% \mathrm{RH}$. The effect of ALE on C. gloeosporioides was assessed 7 days after treatment, by measuring lesion diameter on the fruit surface using a digital caliper. The efficacy of the treatments (ET) was evaluated as described above. The bioassays were prescribed as described above with two trials.

Statistical analysis. Data gathered from the experiments were statistically compared and analyzed using Tukey's HSD test, applying analysis of variance (ANOVA) at $\mathrm{P}<0.05$ significant differences. It was carried out using SPSS software (IBM 20 for IOS, NY, USA).

Received: 30 January 2020; Accepted: 26 May 2020

Published online: 09 July 2020

\section{References}

1. FAO. Mango production, production area and yield by all reporters, 1961-2014 (based on Mangoes, Mangosteens, Guavas). Retrieve October 21, 2016, from the Food and Agriculture Organization of the United Nations (2016).

2. Nuevo, P. A. \& Apaga, A. R. M. Technology reducing postharvest losses and maintain quality of fruits and vegetables (Philippines). In Technology Reducing Postharvest Losses and Maintain Quality of Fruits and Vegetables (Huang, C. C., Yang, C. M., Ou, S. K., Chen, J. J. eds.). Taiwan: Taiwan Agricultural Research Institute, Council of Agriculture Special Publication No. 147, 154-167 (2010).

3. Arauz, L. F. Mango anthracnose: Economic impact and current options for integrated management. Plant Dis. 84, 600-611 (2000).

4. Ploetz, R. C. Diseases of mango. In Diseases of Tropical Fruit Crops (R.C. Ploetz ed.), Vol. 544. 327-363 (CABI Publishing, Wallingford, 2003).

5. Ploetz, R. C. \& Freeman, S. Foliar, floral and soilborne diseases. In The Mango: Botany, Production and Uses (Litz, R.E. ed.) 2nd edn (CABI, 2009).

6. Alvindia, D. G. \& Acda, M. A. Revisiting the efficacy of hot water treatment in managing anthracnose and stem-end rot diseases of mango cv. "Carabao". Crop Protect. 67, 96-101 (2015).

7. Alvindia, D. G. \& Acda, M. A. The antagonistic effect and mechanism of Bacillus amyloliquefaciens DGA 14 against anthracnose of mango cv "Carabao". Biocontrol Sci. Technol. 25(5), 560-572 (2015).

8. Donkin, D. J. \& Oosthuyse, S. A. Quality evaluations of sea-exported South African mangoes in Europe during the 1995/96 season. South Afr. Mango Growers Assoc. Yearb. 16, 1-5 (1996).

9. Sundravadana, S. Alice, D., Kuttalam, S. \& Samiyappan, R. Efficacy of azoxystrobin on Colletotrichum gloeosporioides (Penz.) growth and on controlling mango anthracnose. J. Agric. Biol. Sci. 2, 10-15 (2007).

10. Van den Bosch, F., Paveley, N., Shaw, M., Hobbelen, P. \& Oliver, R. The dose rate debate: Does the risk of fungicide resistance increase or decrease with dose?. Plant. Pathol. 60, 597-606 (2011).

11. Kumar, M. \& Berwal, J. S. Sensitivity of food pathogens to garlic (Allium sativum). J. Appl. Microbiol. 84, 213-215 (1998).

12. Hosseinzadesh, H. \& Sadati, N. The protective effect of Allium sativum L. clove aqueous and methanolic extracts against hypoxiainduced lethality in mice. Short communication. Phytother. Res. 17, 279-281 (2003).

13. Sato, A., Terao, M. \& Ishibashi, M. Antibacterial effects of garlic extract on Vibrio parahaemolyticus in fish meat. J. Food Hyg. Soc. Jpn. 34, 63-67 (1993).

14. Waqar, A., Quaratulain, S., Altaf, H., Ahmad, G. M. \& Asghar, Z. Evaluation of different garlic extracts for antibacterial activity. Sci. Int. 5, 385-386 (1994).

15. Rees, L. P., Minney, S. F., Plummer, N. T., Slater, J. H. \& Skyrme, D. A. A quantitative assessment of the antimicrobial activity of garlic (Allium sativum). World J. Microbiol. Biotechnol. 9, 303-307 (1993).

16. Weber, N. D., Andersen, D. O. \& North, J. A. In vitro virucidal effects of Allium sativum (garlic) extract and compounds. Planta Med. 58, 417-423 (1992).

17. Mangoba, M. A. \& Alvindia, D. G. Acaricidal and chemical composition of Allium sativum L. crude extracts against stored product mites Suidasia pontifica Oudemans. J. Biol. Active Prod. Nat. 9:6, 484-491 (2019).

18. Portz, D., Koch, E. \& Slusarenko, A. J. Effects of garlic (Allium sativum) juice containing allicin on Phytophthora infestants and downy mildew of cucumber caused by Pseudoperonospora cubensis. Eur. J. Plant Pathol. 122, 197-206 (2008).

19. Miron, T., Rabinkov, A., Mirelman, D., Wilchek, M. \& Weiner, L. The mode of action of allicin: Its ready permeability through phospholipid membranes may contribute to its biological activity. Biochem. Biophys. Acta. 1463, 20-30 (2000).

20. Rabinikov, A. et al. The mode of action of allicin: Trapping of radicals and interaction with thiol-containing proteins. Biochem. Biophys. Acta. 1379, 233-244 (1998).

21. Kimbaris, A. C. Comparison of distillation and ultrasound-assisted extraction methods for the isolation of sensitive aroma compounds from garlic (Allium sativum). Ultrasonic Sonochem. 13, 54-60 (2006).

22. Ankri, S., Miron, T., Rabinkov, A., Wilchek, M. \& Mirelman, D. Allicin from garlic strongly inhibits cysteine proteases and cytopathic effects of Entamoeba histolytica. Antimicrob. Agents Chemother. 41, 2286-2288 (1997).

23. Curtis, H., Noll, U., Stormann, J. \& Slusarenko A. J. Broad-spectrum activity of the volatile phytoanticipin allicin in extracts of garlic (Allium sativum L.) against plant pathogenic bacteria, fungi and Oomycetes. Physiol. Mol. Plant Pathol. 65, 79-89 (2004).

24. Shams-Ghahfarokhi, M. et al. In vitro antifungal activities of Allium cepa, Allium sativum and ketoconazole against some pathogenic yeasts and dermatophytes. Fitoterapia 77, 321-323 (2006).

25. Figueiredo, K. V., Olieveira, M. T., Olievera, A. F. M., Silva, G. C. \& Santos, M. Epicuticular-wax removal influences gas exchange and water relations in the leaves of an exotic and native species from a Brazilian semiarid region under induced drought stress. Aust. J. Bot. 60, 685-692 (2012).

26. Vogg, G. et al. Tomato fruit cuticular waxes and their effects on transpiration barrier properties: functional characterization of a mutant deficient in a very-long-chain fatty acid beta- ketoacyl-CoA synthase. J. Exp. Bot. 55, 1401-1410 (2004).

27. Jetter, R. \& Riederer, M. Localization of the transpiration barrier in the epi- and intracuticular waxes of eight plant species: water transport resistances are associated with fatty acyl rather than alicyclic components. Plant Physiol. 170, 921-934 (2016).

28. Vazquez, C. C. et al. Filling gaps in our knowledge on the cuticle of mangoes (Mangifera indica) by analyzing six fruit cultivars: Architecture/structure, postharvest physiology and possible resistance to fruit fly (Tephritidae) attack. Postharvest Biol. Technol. 148, 83-96 (2019).

29. Spalding, D. H. Resistance of mango pathogens to fungicides used to control post harvest diseases. Plant Dis. 66, 1185-1186 (1982). 
30. Kumar, A. S., Reddy, N. P. E., Reddy, K. H. \& Devi, M. C. Evaluation of fungicidal resistance among Colletotrichum gloeosporioides isolates causing mango anthracnose in agri export zone of Andhra Pradesh, India. Plant Pathol. Bull. 16, 157-160 (2007).

31. Brent, K. J. \& Hollomon, D. W. Fungicide resistance in crop pathogens: how can it be managed? 2nd edn. In Fungicide Resistance Action Committee 1-50 (2007).

32. Balamurugan, R., Duraipandiyan, V. \& Ignacimuthu, S. Antidiabetic activity of $\gamma$-sitosterol isolated from Lippia nodiflora L. in streptozotocin induced diabetic rats. Eur. J. Pharmacol. 667, 410-418 (2011).

33. Cerqueira, F. et al. Clionasterol: a potent inhibitor of complement component C1. Planta Med. 69, 174-176 (2003).

34. Endrini, S., Rahmat, A., Ismail, P. \& Taufiq-Yap, Y. H. Cytotoxic effect of $\gamma$-sitosterol from Kejibeling (Strobilanthes crispus) and its mechanism of action towards c-myc gene expression and apoptotic pathway. Med. J. Indonesia. 23, 203-208 (2014).

35. Corzo-Martinez, M. C. N. \& Villamiei, M. Biological properties of onions and garlic. Trends Food Sci. Technol. 18, 609-625 (2007).

36. Singh, U. P. Prithiviraj, B. Sarma, B. K. Singh, M. \& Ray, A. B. Role of garlic (Allium sativum L.) in human and plant diseases. Indian J. Exp. Biol. 39, 310-322 (2001).

37. Koul, O. \& Walia, S. Comparing impacts of plant extracts and pure allelochemicals and implications for pest control. CAB Rev. Perspect. Agric. Vet. Sci. Nutr. Nat. Resour. 1-30 (2009).

38. Feng, R. \& Isman. M. B. Selection for resistance to azadirachtin in the green peach aphid, Myzus persicae. Experientia. 51, 831-833 (1995).

39. Tangtrakulwanich, K. \& Reddy, G. V. P. Development of insect resistance to plant biopesticides: An overview. Adv. Plant Biopest. 47-61 (2014).

40. Koul, O., Singh, G., Singh, R., Singh, J., Daniewski, W. M. \& Berlozecki, S. Bio-efficacy and mode of action of some limonoids of salannin group from Azadirachta indica A. Juss and their role in a multicomponent system against lepidopteran larvae. J Biosci. 29, 409-416 (2004).

41. Ji, S. H., Kim, T. K., Keum, Y. S. \& Chun, S. C. The major postharvest diseases of onions and its control with thymol fumigation during low-temperature storage. Mycobiology. 46(3), 242-253 (2018).

42. Chen, F. et al. Activity of the novel fungicide SYP-Z048 against plant pathogens. Sci. Rep. 4, 64-73 (2014).

43. Ali, A., Mohamed, M. T. M. \& Siddiqui, Y. Control of anthracnose by chitosan through stimulation of defence-related enzymes in Eksotika II papaya (Carica papaya L.) fruit. J. Biol. Life Sci. 3, 114-126 (2012).

44. Siddiqui, Y.; Ali, A. Colletotrichum gloeosporioides (Anthracnose). In Postharvest Decay. Control Strategies (Bautista-Baños, S. ed.) 337-371 (Academic Press, Elsevier Inc., London, 2014).

\section{Acknowledgements}

The authors acknowledge Professor Young Soo Keum and Professor Doo Hwan Kim of Konkuk University Seoul, South Korea, Korea International Cooperation Agency (KOICA), Dr. Jay Connejos, Dr. Brian Lopez and Davao Analytical Laboratory headed by Sir Tony Gumapac for the assistance.

\section{Author contributions}

D.G.A. and M.A.A.M. intellectually conceived, designed and conducted the experiments the experiments. D.G.A. and M.A.A.M. wrote the manuscript.

\section{Competing interests}

The authors declare no competing interests.

\section{Additional information}

Correspondence and requests for materials should be addressed to M.A.A.M.

Reprints and permissions information is available at www.nature.com/reprints.

Publisher's note Springer Nature remains neutral with regard to jurisdictional claims in published maps and institutional affiliations.

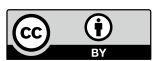

Open Access This article is licensed under a Creative Commons Attribution 4.0 International License, which permits use, sharing, adaptation, distribution and reproduction in any medium or format, as long as you give appropriate credit to the original author(s) and the source, provide a link to the Creative Commons license, and indicate if changes were made. The images or other third party material in this article are included in the article's Creative Commons license, unless indicated otherwise in a credit line to the material. If material is not included in the article's Creative Commons license and your intended use is not permitted by statutory regulation or exceeds the permitted use, you will need to obtain permission directly from the copyright holder. To view a copy of this license, visit http://creativecommons.org/licenses/by/4.0/.

(C) The Author(s) 2020 